\title{
WE ARE ALL HOSTAGES: \\ Report from a Prison of the Polish Military Regime ${ }^{1}$
}

Adam Michnik ${ }^{2}$

This war was not declared. In the course of a Saturday night in December, officials of the security system (Sicherheitsapparat)' hammered on our houses, broke the doors open with crowbars, came in swinging wildy, shot teargas in our eyes, put handcuffs on us, and led us away--as internees--to the prisons. We were the first prisoners in this war of the communist establishment against its own people. The action in the night was the first victorious battle of the General. This is how the resolution of the $9 t h$ Party Congress of the United Polish Workers' Party (PVAP--the communist party in Poland) concerning the incompatibility of the various official posttions of leadership was to be realized. Jaruzelski, at the same time Defense Minister, Premier, and First secretary of the Party, also became head of the "Military Council for National Deliverance". abbreviated WRONA. But wrong also means "the crow" in [Polish]. The Poles will now forever associate the word with the ugly bird, with the caricature of the eagle that ornaments the Polish national coat of arms.

A future historical account will praise the precision of the attack, the perfect selection of the moment, and the able carrying-out of the action. The historians will describe the consistency with which all the resistance of the enemy was broken, and the poets will sing praises to the great military triumphs of this army, which through its struggle achieved the victory in the streets of Danzig, in Warsaw factories. in steel mills, coal mines, and in the shipyards. General Jaruzelski increased the fame of the Polish military by occupying the Warsaw radio station and television station along with the central telephone system building in one skillful maneuver. Truly, since the battle of King Sobieski near Vienna in 1683, none of our leaders have been able to claim such successes. Now the musicians will compose symplionies, the painters will imnortalize the victorious attacks, the film directors will shoot patriotic films, and all for the honor of the leaders of the December night. The Council of state will doubtlessly introduce a new medal-for participation in the campaign of December 1981 . 
But we don't want to joke. Although the government propaganda strikes exactly such a tone, we want, even while still bewildered and shocked, to ask ourselves about the meaning of what has happened in Poland. For in the night of the 12 th to 13 th of December the communist power elite began despairingly to defend its position as the ruling class, its power, and the privileges bound up with this power. The status of the power elite--one doesn't need to ground this in detail--was being threatened, and indeed, not only in Poland, but in the entire communist block. The DecemberPutsch didn't have so much to do with the aim of realizing the communist utopia, but was rather a classic counter-revolution against the workers for the defense off the conservative interests of the ancien regime. Contrary to the official propaganda, this was in no way the response to an attempt to take over the political power: Solidarity had at its disposal neither a shadow cabinet nor a plan for a coup d'etat.

The genesis of the December chaos begins with the fundamentally unresolvable conflicts between a millions-strong social movement organized in solidarity and the totalitarian structure of a communist state. But the fact of the existence of an independent and self-administered institution supported by the people was unacceptable. The issue here wasn' $t$, then, that of power itself, but authority (Machtvollkommenheit), and consequently, the limits of the party nomenclature. with the style of the exercise of power, and, therefore, with the rule of law, with the meaning of the compromises concluded between the governing and the governed--so, about pluralism in social life, about the structuring of self-administration in the factories and at other levels of social life.

The realization of the reform program, which included all these areas, put the fundamental principle of communist leadership over state and society in guestion. It was obvious that the power-structure (Apparat) wouldn't ever freely relinguish even a little bit of its power and the conflicts were consequently unavoidable. We thought, lowever, that matters would take a different course. We didn't believe that the power-structure (Machtapparat) would attempt to resolve social conflicts with military power by using the argument of power instead of the power of argument.

This is not the first crisis in the history of the communist states. Nevertheless, anyone who compares those events which occured twelve years apart, first in 1956, then the Prague Spring, and now the 15 months in Poland, can, despite some similarities, also see some significant differences. Common to each of these situations was the desire for an expansion of national and civil rights. The differences lay in the dymamic of the social changes. 
In 1956 the impulse for reform came from Moscow, from the hall of the 20th Party Congress of the Communist Party of the Soviet Union, where the party bureaucrats did away with the still present shadow of stalin and pushed aside the axe that the security police held over their heads. The movements inside the party, which shook Poland and Hungary in 1956, too, had their origin in these developments. In Poland the authority of Gomulka, who had recently been released from prison, represented a satisfactory guarantee for both the Kremlin and the Polish people. For the Kremlin Gomulka was an obstinate communist, but one with whom they could nevertheless come to an understanding. For the Poles he was a spokesman for their national and democratic desires. In Hungary the opposition of the stalinist wing in the power-structure (Apparat) led to a situation in which the revolution in the streets began to dictate the tempo of the changes. The power-structure (Machtapparat) fell apart like a house of cards. The soviet intervention was a direct consequence of this fact.

In Czechoslovakia in 1968 it was a circle of the power-structure inside the party (Kreise des Apparats innerhalb der Partei) that noticed that the economic inefficiency of the communist system and its susceptibility for waste and backwardness would increase unless there were deep conceptual reforms. The essense of the conflict in Czechoslovakia lay in the desire of the liberal and victorious faction of Dubček--which was supported by the entire society--for democratic reforms from above together with a lessening of the dependence on Soviet centralization. The Czechoslovakian "socialism with a human face" had many faces: from a tempered reformism of the party machine (Apparatschiks) to a pluralistic vision of society, as could be found in the writings of nonconformist journalists. The determining factors, however, were the opposition of the Czechoslovakian leaders to the dictates of the Soviets and their desire to seek the legitimation of their power in the support of their own society and not only in the official chambers of the Kremlin.

It was different in Poland. It is hard to speak of a "socialism with a human face" here; it was previously a "communism with its teeth knocked out", a communism which could no longer bite and defend itself against the assault of organized society. This social presure had nothing to do with the use of force. Contrary to the hysterical explanations about "open counter-revolution" and the "Eascist terror in the factories", no one was killed in the Polish revolution, not a drop of blood was shed. Many observors ask the question, "how is this to be explained?"

The development of the Polish reform movement--or the Polish self-limiting-revolution (sich-Selbst-beschraenkenden Revolution)--had its origin outside the 
institutions of the official public life. For many years groups of a democratic opposition have existed and operated in Poland, groups which were widely supported by broad circles of public opinion and protected by the effective umbrella of the church. Under the relatively tolerant course of the Gierek regime (Gierek-Equipe)--a tolerance that, by the way, developed because of connections with the West and political weakness and not exactly out of a spirit of political liberalism--attempts were undertaken for self-help and social self-defense, an independent intellectual life was organized, and uncensored scenarios were sketched of a struggle for freedom.

The central point of the program of these opposition circles--the most popular of which was the "Committee for the Defense of the Workers" (KOR), which was formed after the strikes in June 1976--iay in the desire to change the society and to rebuild social connections outside the official structures. The central question wasn't, "how can one reform the system of the use of power?" , but, "how can one defend oneself from this system?"

This way of thinking effected the course of the August strikes, the form of the strike demands, the program, and the strategy and tactics of Solidarity. The passionate struggle for the reform of the totalitarian structure lasted 15 months. The high point of the struggle was as equally untypical as its course. The official declaration of war on the society stemmed from the nature of the preceeding conditions. War, according to clausegitz, is the continuation of the politics pursued in peacetime with other means. This time it was a war against the organized society taken up by a state which is an instrument of the organized political power of the Warsaw Pact. The analysis of the mistakes which Solidarity made will long remain a topic of Polich political discussions. For the people and a woman--to recall the appropriate formula from Karl Marx--will the moment of neglectfulness never be forgotten in which they allowed a scoundrel to rule them.

The union, actually a front for national solidarity, bore in itself the good and bad sides of that society which gave birth to it; a society which for 37 years has lived estranged from every democratic institution and outside the sphere of political culture; a society which was systematically lied to. stultified, and humiliated; a society which is at the same time obstinate and deliberate, in which honor, freedom, and solidarity have the highest values and compromise is all too frequently equated with capitulation and being a renegade.

Solidarity was a democratic movement of the world of the workers, which functioned in an anti-democratic environment. inside the totalitarian structure of a 
system whose only understandable legitimation lay in the agreements of the Yalta Conference. The Poles don't need to be reminded on the contents of these agreements, as Mr. [Henri) Nannen" did recently, who seems to think that human rights are due only to those who live west of the Elba, while the whip and barbedwire remain reserved as appropriate instruments to regulate the mechanisms of public life for the barbarians of the east. The Poles haven't forgotten Yalta. The problem nevertheless existed of how to translate the realities of Yalta into a contemporary language. That was not simple.

The powerful, spontaneous social movement, which shaped itself from one day to the next without a model and in the middle of on-going conflicts with the powerstructure (Machtapparat) had no unequivocal, welldefined stage-by-stage goals and no clear conception about coexistence with the communist regime. It allowed itself to be easily provoked into discussions about unimportant things and there existed many superfluous conflicts within it, much disorder, inefficiency, and a lack of knowledge of the opponent and his methods of action.

Solidarity could strike, but it couldn't wait. It had a cominand of the techniques of direct attack, but not that of retreat. It had fundamental ideas, but no program for stage-by-stage actions. It was a Collossus on steel feet, but with hands of clay. It was powerful in the factories, inside the workers groups, but helpless at the bargaining table. It had an opponent which wasn't in the position to tell the trutl, to hold the economy in gear, or even to fulfill its own obligations, but which could do one thing: smash the social solidarity to pieces. It had learned this art to perfection in its 37 years in power.

This opponent--the power-elite--was morally and financially bankrupt, and was, because of its political weakness, incapable of realizing any political program. This political weakness was understood by Solidarity as a general weakness, whereby one forgot that an apparatus of power (Apparat der Gewalt), untroubled by denocratic corrosion, can be a useful instrument in the hands of a dictatorial power, and above all in the hands of a dictatorship which finds itself in hot water.

The communist system in Poland was a Collussus on clay feet, but with iron hands. When they denanded democratic elections of the parlianent and the people's councils, the officials of solidarity seemed to forget that such slogans set off an alarm signal in the ruling class and announced their soon-to-come end. We repeat: Solidarity never demanded that the communists be expelled from the government and that the state be replaced with the administrative structure of the union (Gewerkschaftsapparat). Nevertheless, it is a problem 
that the governing cliques (Apparatschiks) read such a program into the declarations of solidarity--but it is now unimportant to what extent it must have been so.

They noticed the pressure of the political base (Drang der Basis) to disolve the party comnittees in the factories; the specter of the elections for the people's councils frightened them; they had nightmares about [the possibility of] a national referendum concerning the form of self-administration; and they saw that a drastic raising of prices was due. Their response to all of this was the coup of December, the last response at their disposal. Solidarity didn't expect a military coup and was taken completely by surprise. The workers' groups don't carry the responsibility for this, but ali those who, like the author, were called upon on the basis of their intellectual activities to form the political vision of the union, do.

The theoretical reflections--this only as a parenthetical comment--on the topic of changing the system limped along behind the events. Except for on-going slogans there was hardly any political reflection. Praxis finally overtook theory--and not for the first time in the history of Poland.

The fundamental, if also never clearly defined, conflict within Solidarity concerned the tempo of the changes and their extent. At the beginning the adherants of a compromise solution were in the majority. but in time it became obvious that the power-structure (Machtapparat) interpreted every inclination to compromise as a weakness. Every concession had to be extorted through strikes or the threat of strikes.

The constant strikes, skillfully provoked by the power-structure (Machtapparat), wore down the society, which was exhausted by the difficulties of every day life. Positive results in the form of detectable improvements in the guality of life didn't appear and this led to polarization and put the meaning of this tactic in question. One group would say: "No more strikes, that accomplishes nothing." The other said: "No more ineffective strikes, we need a general strike, which will force the government to essential concessions." It is hard to say which group was the largest, but it is certain that the second group was the most vocal. And exactly that group, mostly young workers from large factories, demanded radical action from the leadership of Solidarity, which became harder and harder to hinder (although Walesa and Kuron attempted to do this).

The power structure (Machtapparat) was scoined more and more and not taken very seriously. Almost no one believed that it might be possible to use Polish soldiers to attack Polish workers; almost no one believed in the possibility of a military coup. The fundamental reasons for this were naiveté and wishful thinking--and also the long tradition of Polish history. AC- 
cordingly, the attempt to terrorize Polish society with the help of the Polish army seemed hardly imaginable. The preceeding months had fixed in the public consciousness a pattern of the development of the conflicts between state and society in which there was no place for an open victory. The plans for gallows and detention lists existed only in the sick imaginations of the party notables.

The union knew only one response to the attack of the government: an occupation strike. This tactic was rendered ineffective when the army stormed the factories. But the consciousness of the futility of peaceful forms of resistance can have catastrophic consequences. The blood shed by the mine workers from the mine "Wujek" can become a constructive lesson in the kind of language one must use with the government if one wants to achieve something.

What did the communists think of solidarity? The August crisis was no surprise to them, although the course of the strikes, the maturity of the demands, the discipline and solidarity of the workers' groups shocked them. For the Gierek regime, which came to power on the wave of the bloody uprising of the dock workers in 1970, it was a dogma to avoid an armed confrontation with the working-class. The recognition of an independent union in 1980 was an act of desperation accompanied by the belief that it might be possible to limit this movement to the coast of the Baltic and eventually manipulate and destroy it from within. When the wave of strikes in August then forced the recognition of a unified union at the national level, the power-structure (Apparat) could only hope to wear it down with provocations and to split it from within. Solidarity presented a deadly threat--it dissolved (liquidierte) the fundamental principle of communist ideology that the communist party represents the working class.

The plan to destroy the union with "political means" failed. However, the constant conflicts--over political prisoners, free Saturdays, and the registration of the farmers' union--just like the personality conflicts, inspired from outside, weakened the union. But in no way did this improve the situation of the power-structure (Apparat): for it, already hopelessly divided and poisoned by the struggle for power, there arose a predominating problem--the party.

The party, understood as the organized community of its members, was not at all present during the August strikes. This instrument, which in earlier times was useful to the power-structure (Apparat) as a means to break down the social solidarity, had itself broken down this time. In its attempt to bring the party back to $11 \mathrm{fe}$ the power-structure (Apparat) actually opened up the proverbial Pandora's Box. On the one hand, there was the attempt to find a scapegoat, which led to 
the publicizing of the ever more shocking proofs of corruption in the Gierek regime. On the other hand, party members began to turn their membership cards in, or worse yet, to integrate themselves into the "structure of the bases" (Basis-strukturen), which demanded the democratic reform of the party, a canceling (Aufhebung) of the stalinist model that the powerstructure (Apparat) had used to defend its position of absolute power.

In this situation we can finally see the fundamental differences between the recent events in Poland and the crises of the years 1956 and 1968. Then the communist leaders (Nagy, Gomulka, Dubceck) were in the position to gain for themselves the trust of the society; those in the group who favored party reform from above had public support at their disposal. But in Poland the entire party dragged itself along behind the changes. The party didn't stimulate the changes in society; it was instead a social movement outside the party (PVAP) that brought changes in the party ine. The reform program of the party was--from the perspective of the goals of solidarity--a crass anachronism.

The party reformers in Poland formed no unified camp. Among the people who were designated as reformers were such different individuals as Andrzej Werblan, one of the ideological dictators in the era of Gomulka and Gierek, the well-known journalist stefan Bratkowski, one of the organizers of the discussion circle "Experience and Euture" and chairman of the journalists' union, Wojciech Lamentowtcz, a 36-year old scientific fellow in the party school, and Abigniew Iwanow. party secretary and leader of the August strikes in a factory in Torun.

But despite their differences, they all became sacrifices to the paradox that belongs to the fate of communist reformers throughout the world: they demanded the reform of a totalitarian party in the name of human freedom and social justice--against the bureaucratic structure (Apparat) which supresses freedom of thought and creativity and prefers mediocrity and corruption. For this reason they could only attack the powerstructure (Apparat) effectively if they organized a collective movement, but not in a faction which fought over the power. As a faction they automatically hung on outside the party and were additionally compelied to use in daily political battles the same practices which they sharply criticized when used by opponents. The "base-structures" (Basisstrukturen) of individual party cells were an attempt to solve the problem of the squaring of the circle. But they were too weak to succeed and wholly macceptable to the power-structure (Apparat): they couldn't hold together against the massive counter-attack of the conservative structure of the party. 
The Polish party reformers of this last era showed themselves to be caricatures of the spiritual fathers and older brothers from the Polish October and the Prague Spring. Their reformism seemed to be less abstract and rooted more in everyday life. It contained no dogged debates over the philosophy of the young Marx, but, instead of this, discussions over economic reform. But nothing turned on discussions about beginnings. This movement found no support in the everyday discussions of the people over the reforms. It was at the same time a descendant and the final stage of the ideal destruction process of real communism. The people helped themselves to an ordinary language way of talking about things, while the ideas of the party reformers remained hanging in the tongs of MarxistLeninist Newspeak. For the party reformers the central question was, "how can one democratize the party?", what should be the key to the democratization of the party? For the people the central question was, "how can one snatch away as many spheres of public life as possible from the dictatorship of the party nomenclature?"

The party structure (Parteiapparat) accused solidarity of being a political party and not a union. Solidarity suggested to the PVAP that it should develop into a political party which might struggle for credibility in the society instead of persisting to stand still in the position of union of the members of the power structure (Machtapparat). This was the most precise definition of the social character of the ruling communist party. And that was decisive. The democratic course of the 9 th Party Congress of the PVAP changed little of this--for the people who were selected in a democratic way for the highest positions were already compromised, including Albin siwak, who should be presented as a Polish stacanow, a model worker with the identification papers of the security police in his pocket. With the siwaks in the Politburo the PVAP couldn't count on being considered credible by the people. The new leadership and the ratified program of the Party Congress were still-born. The powerstructure (Apparat) could now only hope for a split within the union and for the mediating role of the Church.

This is exactly what they built on. The idea was for a Front of National Understanding, the pillars of which should have been the power-structure (Machtapparat), the Cliurch, and Solidarity, which was symbolised by the meeting between Jaruzelski. Primas Glemp, and halesa. That was the last attempt to outmaneuver the union "without bloodshed". The Catholic Church, the greatest moral authority in Poland--and additionally strengthened because of a Polish Pope-was inclined without doubt to a compromise solution. It endeavoured to build bridges for an agreement, to sub- 
due tensions, and to be a moderating influence on both the power-structure (Machtapparat) and Solidarity.

But it should have been a compromise, not a renunciation by the union of its principles and goals. For the common lists suggested by the power-structure (Machtapparat) for the September 1981 municipal elections represented nothing else but such a renunciation--a solution which the church couldn't and didn't want to support. That was the turning point. For the union it became clear that conflict was unavoidable; to the power-structure of the state (staatsmacht) it seemed obvious that the possibility of a compromise had been taken as far as it could be.

One must concede that the action taken in the night of December, to which the total unscrupulousness of its executors had contributed, went off perfectly. With tanks and bayonets the union was "pacified", the resistance of the workers in the factories was broken. This triumph of the power-structure (Apparat) can, however, have unexpected consequences. It could become proof of political short-sightedness. With a bayonet one can spread fear, terrorize, kill and strike victorious blows against an unarmed people. But one sits badly on a bayonet--a thought from Talleyrand that stefan Bratkowski used to quote. And with a bayonet, we add, one can't pick out the memory of 15 months of freedoin from the people.

We have already looked for an answer to the question of how the state power (staatsmacht) was able to break the resistance in such a short time. Besides the shock of surprise and the conviction that the spilling of blood is a barrier for all poles that shouldn't be stepped over, there was still another factor that determined the course of events: the shadow of Russia. The problem of Soviet intervention was often discussed. Press reports confirmed daily the unmistakeable intentions of Moscow. We knew that solidarity was not loved in the kremlin.

There were conflicts over the assessment of the intentions of Soviet policy, which in the Afghanistan conflict was involved in internal difficulites and a complicated international game. There was no clarity in this. Some of us quietly pursued the hope that it might be possible to create a model Polish-soviet relationship in which a place might be given for Poland as a free state (als subjekt). We also believed that the Soviet Union would only decide in favor of armed intervention in an extreme situation, in the event of a civil war or an attempt to take over power. We were of the opinion that those who held power in Poland had hastily used the frightful picture of the soviets in order to achieve the psychological affect of an intervention without an intervention.

The course of events proves that these considerations were rational: the soviet Union did everything 
possible to conceal its participation in the December coup. The scenario that it played from was optimal in the view of the Soviets: "the Poles have made a solution to their problems for themselves". [But] the declaration of a state of war must have reminded the people of the Targowica, one of the dirtiest symbols of national shame. (The Confederation of Targowica decided against the constitutional reforms of 1792 and called on Russian troops for help, which led to the Second Partition of Poland.)" The frightening specter of Soviet intervention in the event that Jaruzelski was defeated determined the behaviour of the Poles. I risk this hypothesis in the conviction that it might be a further argument for how great the stock of rational ideas and healthy human reason is in this romantic people, a further argument that the Poles can't only fight, but can also think.

No one in Poland counted on help from the West, so the strong reaction of western public opinion and governments is a rather pleasant surprise. This echo gives us courage and in time can also contribute to restraining the wave of repression. The indignation of world public opinion has an important moral dimension, because it emphasizes that democratic values are not divisible, that these values have their defenders all over the world, and that they don't cease to have value when they are trampled on by soldiers' boots. For men who are imprisioned or being persecuted this is an injection of hope, a true light in that gloomy tunnel which repiesents every day life in Poland under martial law.

The actions of governments have their political dimensions. They are a plece of the larger international strategy in which the Polish question is only an episode. One shouldn't have any illusions that it is otherwise. But one element of this strategy--the demand for economic sanctions--merits closer consideration. I don't know what President Reagan's motives were. I doubt that the announced sanctions were an expression of his anger that Solidarity wasn't successful in restoring capitalism in Poland--as the official propoganda in Poland claimed. If that were the case, Reagan must be pretty weak-minded.

I believe that the sanctions are a response of the West to the military coup that everyone could have expected and the responsibility for the consequences falls back on the organizers of the coup. Jaruzelski and the military council, not Reagan or the Pentagon, bear the guilt for the catastrophic consequences of the sanctions on Polish families. The economies of the comnunistic states cannot manage without western teclinology and raw materials because they are dependent upon them. Nor do great amounts of credit serve unconditionally as factors for the acceleration of reform-the case of Gierek teaches mucl in this respect. And 
it is even less likely to reform an economy with the help of bayonets, denunciations, and policemen. As a consequence, the credit has also fallen into the dust. What wonder that this is not a very encouraging perspective for the West. Can one blame the western politicians that they would like to have a Polish government for a partner that had at least a minimum of credibility with its own people? That they make the granting of further credit dependent upon a restoration of civil rights in Poland?

The official propaganda attempts to portray the sanctions as an attack against the existence of the Polish people. It claims that the sanctions hinder democratic reforms and will damage Polish sovereignty. I am not an advocate of sanctions, but it is sheer cowardice to push the responsibility away from oneself in the matter of who is to blame for the sanctions. It wasn't Reagan who ruined the Polish economy, but those who put their own narrow, selfish interests before the spiritual and material fate of the Polish people. What has to happen before these people understand that they only isolate themselves from their own people and the entire civilized world by the destruction of independent institutions with the application of the methods of a military-police dictatorship?

What does the future hold for Poland? Every evening conversation in Poland turns on the answer to this question and the discussions continue despite the evening curfew. In the night from the 12 th to 13 th of December the ruling communists returned to their original status of 1945--to the position of a relatively small sect which depends on the bayonet for its power. It was at that time a sect of pro-soviet Jacobins; today it is a sect of pro-Soviet Mandarins. Then they defended their program; today they defend their privileges.

Historical experience suggests two different models for the resolution of such crises. The first we understand under the name Kádár, the second with the name Husák. Janos Husák in lungary began his excercise of power in 1956 as a soviet state holder who depended upon Soviet tanks. The first years of his reign were marked with a cruel policy of repression, which followed a slow "tightening of the screws" from above. Gustav Husák in the CSSR declared from the beginning his intentions to continue the "Prague Spring". After the Soviet intervention all the previously established institutions of public life that had been founded still functioned at first. But the process of their dissolution continued very slowly. The people were forced to humiliating self-criticism and to the denunciation of their colleagues at work. "Extremist elements" were shut off, independent institutions were dissolved--and all this under the pretext that at least the rest of the work of the reforms had to be saved. In this way 
the "Prague Spring" was murdered by the hands of its creators.

The Kádár model is the way from a socially destructive repressive action to the policies of a paternalistic liberalism. The llusak model leads in contrast from a fictitous continuation of democratic structures to a total sterilization of the public life. Kádár is a positive hero for the Polish communists, whose way they would gladly repeat. Judicial judgments are accompanied with claims that the program of renewal and reforms is being continued. The scenario of actions is already discernible: Solidarity must be eradicated, the totalitarian institutions must be capable of functioning again, and the hope of a life worth living must be eliminated from the hearts of the people.

Solidarity is to be eliminated with the hands of its previous leaders, who--broken and humiliated--have signed declarations of loyalty. The agents of the military council tried hard to move Walesa to the acceptance of such a plan. They had no success. A Solidarity without Walesa, Bujak, slowik could only be a dummy, which would only conceal anti-worker policies-a broadiy constructed action of political repression, limited by the protests of Polish and international public opinion, including the "pacification" of the factories, the arrest of union officials, and a propagandistic slander campaign. At the same time, statements will be made repeatedly that everything is in order, that the situation in Poland from day to day is more normal.

But words of truth about the state of the nation resound from the pulpits of the churches--the only place where the language hasn't been contaminated. They speak of repression and of actions to help the victims. One learns in other places that there is resistance. Illegal newspapers are being published; independent institutions are being reestablished. No, this movement is not going to be subjugated. Here, in my new "at home". which is watched over by armed men in uniforms and secured by bars and barbed wire, only bits and pieces of news from Poland and the world get through. But there is more time to put the pieces together.

These 15 months were a lesson in freedom. One can wash "Solidarity" from the facades of the houses, but not from the memory of the people. How of ten the guiding character (der wegweisende Charakter) of the Polish political experience has been emphasized, this political struggle without bloodshed or the use of physical force--a struggle which existed in the reestablished social bonds outside the official structure! This model will function once again under different conditions: it can prove to be useful not only for Poland, but also in other societies of this geopolitical zone. 
But one should also keep in mind that the mechanism of the Polish coup d'etat can also serve as guidepost (Wegweiser). Until now there was never a time when a military elite held the power in a communist system. Ordinarily the party machine (partelapparat) itself was such a power and--in times of intensified terror--the state security police. The military had value only as an instrument and if it made an attempt to become the acting power, it was eliminated. The fate of the soviet marshalls Tuchatschewski and schukow seem to be rather convincing in this respect.

The Polish military coup can thus become a precedent. There is value in considering the hypothesis that perhaps when Jaruzelski took up the task of wiping out solidarity he didn't, whether he wanted to or not, also make the power of the party machine (Macht des Parteiapparats) into a fiction. Until now it was the party machine which ruled, while the army served as its armed right-hand man. Perhaps it is the case today that the military power-structure (Militaerapparat) rules and the party forms only a facade for the exercise of power.

A military coup is one of the techniques for changing society. It is a form which doesn't necessarily determine the content. With a military coup a military dictatorship was founded in Chile, but in portugal a military coup opened up the way to democracy. The military, the only more or less sovereign institution (struktur) over against the party and the security apparatus in a communist system. can play different roles. An army, which, for example, is involved in the unpopular war against the courageous Afghani folk (which Karl Marx in the 19th century called the "Poland of Asia") can play an entirely different role than in Poland, which the Polish example itself can paradoxically be used to show.

Here, behind bars, every gesture of human solidarity, is like a breath of fresh air. For this, I, in my own name and that of my colleagues, am heartfully thankful. Every good report helps. However, there are moments that are more difficult. When, for example, a German Social Democrat gives assurances that the situation for the internees is satisfactory and thereby appeals to the words of the Vicepremier of the People's Republic of Poland [Rakolowski], then I must with bitterness think on the fate of German Social Democrats of 45 years ago and the assurances of different foreign statements that everything is "okay" in Germany, that the opponents of peace and order were being humanely treated. A rulirig vicepremier who steps forward as an expert in the matters of his arrested opponents is a grotesque and lamentable figure--his German partner in conversation is either cynical or naive.'

A few words about the internees. We are prisoners without an arrest warrant from a prosecutor. Each of 
us is free to go at any time he's prepared to sign a loyalty oath and to play the role of a police confidant. A broken man, according to the conviction of our guards, is no longer capable of resistance. All of us--workers, farmers, intellectuals--are hostages. Our fate should be a warning for other colleagues, our status a calling card for foreign lands, and we ourselves shall be an exchange token. Worse things are reserved for those who were sentenced because of participation in strikes.

As everyone else, we have also entered into a new situation because of the "Polish-Jaruzelski War" as its called in the Warsaw venacular. It is difficult today to come to a unified formula for action. Everyone must answer the question before his own conscience of how he is to oppose such evil. Only each of us alone can decide how he is to defend the dignity of man, how he will act in this strange war, which--one must constantly remind himself of this--is a new incarnation of the centuries old battle between truth and falsehood, between freedom and the use of force, between dignity and humiliation.

We repeat, therefore, that in this war there is indeed no final victory, but also no final defeat--and in this belief there is a precious bit of optimism. The belief that there can be no final defeat has moved me to wite out these reflections. This is my contribution in this war. I will certainly not be able to speak my mind so soon again. For this reason I wish my friends, most of all those persecuted and struggling. much strength, so that they can walk boldly through the darkness that lies between hope and despair.

And also much patience, so that they can learn the difficult art of forgiveness.

\section{NOTES}

'Title supplied to a manuscript smuggled out of Poland and published in the German newsweekly Dex Spiegel (March 8, 1982, pp. 128-132) by the editors of the German publication; Copyright 1982 Der Spiegel. Translated by Jon Mark Mikkelsen, with the friendiy assistance and helpful criticism of Herrn Eritz Seitz, Tuebingen, $W$. Germany.

${ }^{2} \mathrm{As}$ an introduction to the essay and by way of suggesting its philosophical and historical significance, it is appropriate to provide some information about the author. The 35 year-old Michnik is the son of Helen Michnik, historian and medieval specialist and ozjasz szechter, who was an active figure in the communist 
movement in Poland before the second world war. Szechter was imprisoned many times during this period and after the war worked as an editor in the Warsaw party publishing house "Book and Knowledge". He, along with others, helped prepare the Polish translation of Das Kapital. As a 15 year-old student in the Warsaw Batory Gymnasium, Michnik, along with his friends, took advantage of the freedom of the immediate poststalinist period and founded the "Club of the contradiction Seekers"; during this same period.he also came to know Jacek Kuron, who was his group-leader in the communist youth organization, the Pathfinders. Active in the opposition student movemnet of the $1960^{\prime} \mathrm{s}$, Michnik studied under Leszek Kolakowski. As a leader of the "Polish March" in 1968, he, like Kolakowski, was forced to leave the university and was subsequentiy sentenced to a three-year prison term. He has been arrested more than 30 times and was allowed to travel in western Europe in 1976 only because of the intervention of Jean-Paul Sartre.

We recognize that Michnik's text is understandably polemical and not strictly philosophical, but we feel that it merits publication in this journal not only as our own "contribution" to what Michnik refers to as the need to "defend the dignity of man ... in this strange war" which has existed in Poland since the 13th of December 1981, but also for the light it may shed for an understanding of contemporary and future philosophical movements in eastern Europe in a period when the former dreams of Eurocommunism seem to have all died. When compared to the western-oriented military regimes that currently rule or have ruled in Turkey or Argentina, or even many of the paper-democracies of Central America, or in the Phillipines, or even South Korea, it might well be the case that the Jaruzelski regime has achieved a kind of "totalitarianism with a human face" if not the "Socialism with a human face" dreamed of in eastern Europe two decades ago. But that Michnik has given up on the possibility of reconciling the ideals of the humanistic Marxism of the $1960^{\prime} \mathrm{s}$ with the political structure of the communist states of eastern Europe must surely not be doubted after reading this document.

Further information on Michnik's life and career can be found in the brief article which accompanied this text in the same issue of Der Splegel ("Adam

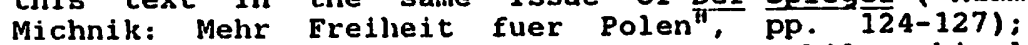
additional information on the current philosophical situation in eastern Europe is also available in two recent issues of Telos (Spring 1981 and Spring 1982).

'As no clear equivalents exist in Engljsh for the terminology used in the German text to describe the political hierarchy of the communist governments of 
eastern Europe, the German expressions have been inclucled in parenthesis.

${ }^{4}$ An editor of the more popular German newsweekly Stern.

5Stacanow was a "model worker" of the post-war Stalinist era in the Soviet Union.

'Explanation of the Targowica in parenthesis supplied by the German editors of Der Spiegel.

${ }^{7}$ Rakolowski's contrasting account of the events in Poland can be found in an extensive interview published in Stern (January 3, 1982, pp. 12-21). This account is accompanied by a sympathetic editorial written by Henri Nannen. 